\title{
Determinants of Poverty in Indonesian Provinces
}

\author{
Sri Nawatmi \\ Department of Finance and Banking \\ Universitas Stikubank \\ Semarang, Indonesia \\ nawatmi@edu.unisbank.ac.id \\ Agus Budi Santosa \\ Department of Management \\ Universitas Stikubank \\ Semarang, Indonesia \\ agusbudi@edu.unisbank.ac.id
}

\author{
Agung Nusantara \\ Department of Management \\ Universitas Stikubank \\ Semarang, Indonesia \\ nusantara@edu.unisbank.ac.id \\ Muhaimin \\ Department of Management \\ Universitas Stikubank \\ Semarang, Indonesia \\ muhaimin@edu.unisbank.ac.id
}

\begin{abstract}
Poverty is a global problem faced by a lot of countries, including Indonesia. In this research, the data used are 34 provinces in Indonesia from 2015-2018. The analysis technique used is data pooling that combines times series and cross section. The research result shows that the suitable model to analyze poverty is the fixed effect model. Variables that have a negative effect on poverty are Gross Regional Domestic Bruto per-capita, Sanitation, and net enrollment rate of senior high school, while Gini Ratio has a positive effect. Based on the analysis, there are 14 provinces that have higher poverty percentage than the average province poverty in Indonesia.
\end{abstract}

Keywords: poverty, provinces, data pooling, fixed effect model

\section{INTRODUCTION}

Poverty is a global problem faced by a lot of countries, especially developing countries. Developments in many sectors are conducted by many countries to overcome poverty. Beside high economy growth, the main purposes of development are decreasing poverty, treating income imbalance, and providing vocation in terms of growing economy [1]

Poverty and income imbalance will hinder economic growth rate itself. It happens when capital accumulation, as a positive impact of income imbalance, is balanced by the low accumulation of human capital as a negative effect of [2]. Poverty and income imbalance also create social instability, uncertainty, and humanity tragedies such as starvation, low health level, and malnutrition.

Development equitability and poverty treatment become priority of economic development in Indonesia. Economic development is conducted to strengthen economic structure by making the industrial sector a driving force supported by efficient agricultural and mining sectors and effective service activities.
Poverty level in Indonesia declines from 2015-2018 (Fig.1). However, the poverty level in Indonesia is still high. In March 2015, the number of poor people in Indonesia is 28,59 million (11,22\%), March 2016 became 28,01 million people (10,86\%), and got lower in March 2017 by 27,77 million people (10,64\%), and at last, in March 2018 by 25,95 million people $(9,82 \%)$

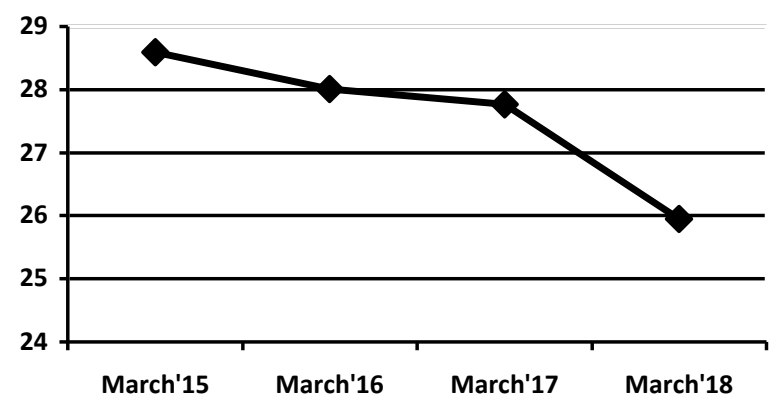

Fig. 1. Poverty level in Indonesia. Source: Central Bureau of Statistics

The causes of poverty are low levels of education and health, limited employment opportunities and conditions of isolation [3]. There are five factors that influence poverty, namely education, type of work, gender, access to health and infrastructure and geographic location [4], [5], [6]. These factors are interrelated which form a cycle of poverty.

The results showed a negative relationship between poverty growth and average income growth [7], [8]. Other researchers have also shown that the number of poor people is influenced by GRDP (Gross Regional Domestic Product), population and education level [9]. But the results of these studies contradict the results of other studies. He stated that 
economic growth is not always the best way to reduce poverty. The combination of growth and income redistribution is the most effective way to reduce poverty in many countries and not all redistribution policies have the same level of effectiveness for every developing country [10].

\section{METHOD}

\section{A. Data and Data Source}

The data used in this research was secondary data. The data resources derived from BPS (Central Bureau of Statistics) in every issue. The data used is the percentage of poor people (HCI- Head Count Index-P0), PDRB (Gross regional Domestic Bruto), sanitation, APMSMA (Net Enrollment Rate of Senior High School) and Gini Ratio. In this research, the Data Pooling used is between 2015-2018 in 34 provinces in Indonesia.

\section{B. Research Model}

The model used in this research is:

$$
\begin{aligned}
\mathrm{HCI}= & \beta_{0}+\beta_{1} \mathrm{PDRB}+\beta_{2} \mathrm{SANI}+\beta_{3} \mathrm{APMSMA}+ \\
& \beta_{4} \mathrm{GINI}+\varepsilon
\end{aligned}
$$

Where:

HCI : Head Count Index

PDRB : Gross regional Domestic Bruto

SANI : The percentage of household with access on proper and sustainable sanitation (under 40\%)

APMSMA: Net Enrollment Rate of Senior High School

GINI : Gini Ratio

$\beta_{0} \quad$ : Constant

$\beta_{1-4} \quad$ : Coefficient

$\varepsilon \quad$ : Disturbance Error

\section{Operational Variable Definition}

From some variables used in this research, the operational definitions are explained below:

1. HCI is the percentage of the population below poverty level (percentage).

2. PDRB is real regional income per capita (thousand Rupiah)

3. SANI is the percentage of household with access on proper and sustainable sanitation (percentage)

4. APMSMA is a ratio between the number of high school students and the number of populations in high school age multiplied by $100 \%$.

5. Gini ratio is a tool to measure income distribution imbalance.

\section{Analysis Method}

This research used pooled data. Pooled data is a set of data consisting of sample and individual data that combine cross section and time series data. By accommodating information related to cross section and time series variables, pool data substantially able to decrease omitted-variable problems; a model that ignores relevant variables [11],[12].

Pooled data is useful for technical-pragmatic reasons that are related to data availability. By combining time series and cross section data, the observation numbers would increase automatically without conducting any data treatment. Thus, pooled data might give a satisfaction solution.

\section{RESULT}

The analysis started from data regression by using pooled data. Next, the best model among three models (Common Effect Model, Fixed Effect Model and Random Effect Model) was chosen.

\section{A. The Best Model Test}

First, regression was conducted by using common effect model and fixed effect model to determine the best model from Common Effect Model, Fixed Effect Model and Random Effect Model. Chow test model was used to determine the best model. The result showed that probability score of cross-section Chi-square is smaller than $5 \%$. It means that the best model is Fixed Effect Model.

\section{TABLE I. CHOW TEST}

\begin{tabular}{|l|l|l|}
\hline Effect Test & Statistic & Prob. Value \\
\hline Cross-section F & 302.856091 & 0.0000 \\
\hline Cross-section Chi-square & 630.299576 & 0.0000 \\
\hline
\end{tabular}

The next step is to determine the best model between fixed effect and random effect by using Correlated random effectHausman Test. The result showed that the probability score of cross-sections random was below 5\%. It means that the best model for further analysis is Fixed Effect Model.

TABLE II. HAUSMAN TEST

\begin{tabular}{|l|l|l|}
\hline Test Summary & Chi-Sq Statistic & Prob. Value \\
\hline Cross-section random & 13.151085 & 0.0106 \\
\hline
\end{tabular}

The model assumed that individual differences (crosssection) could be accommodated from the intercept difference.

\section{B. Hypothesis Test}

Table III showed that in general Gross Regional Domestic Bruto, sanitation, and Net Enrollment Rate of Senior High School (APMSMA) influenced negatively towards poverty of 34 provinces of Indonesia, whereas Gini ratio influenced positively.

TABLE III. FIXED EFFECT MODEL

\begin{tabular}{|l|l|l|}
\hline Variable & Coefficient & Prob. Value \\
\hline C & 15.40535 & 0.0000 \\
\hline PDRB & $-4.92 \mathrm{E}-05$ & 0.0587 \\
\hline Sanitation & -0.053484 & 0.0000 \\
\hline
\end{tabular}




\begin{tabular}{|l|l|l|}
\hline Net Enrollment Rate SHS & -0.039223 & 0.0806 \\
\hline Gini Ratio & 6.997391 & 0.0847 \\
\hline R-squared & 0.994653 \\
\hline Adjusted R-squared & 0.992634 \\
\hline F-statistic & 492.6870 \\
\hline Prob. (F-statistic) & 0.000000 \\
\hline
\end{tabular}

The F statistic test showed that Gross Regional Domestic Bruto, sanitation, Net Enrollment Rate of Senior High School (APMSMA), and Gini ratio influence poverty in Indonesia. The Goodness of fit $\left(\mathrm{R}^{2}\right)$ value is $99,4653 \%$. It means that the model is able to explain the total variation of poverty in Indonesia by $99,4653 \%$. Accordingly, the model ability in explaining poverty in Indonesia is huge.

The result of regression showed, there are 14 provinces that have higher poverty percentage than the average province poverty in Indonesia. They are Aceh, Sumatera Selatan, Bengkulu, Lampung, Jawa Tengah, DIY, Nusa Tenggara Barat, Nusa Tenggara Timur, Kalimantan Timur, Sulawesi Tenggara, Gorontalo, Maluku, Papua Barat, and Papua. Among those provinces, Papua Barat, Papua, and followed by Nusa Tenggara Timur are three provinces with the highest percentage of poverty in Indonesia.

\section{DISCUSSION}

The result of 34 provinces' poverty showed that Gross Regional Domestic Bruto per capita influenced negatively towards the average poverty of provinces in Indonesia. It happened as the decreasing income per capita caused a decrease in people's ability to fulfill basic needs such as food and others. The decrease of people purchasing power caused the increase of poverty. In contrast, the increase of income per capita caused bigger people purchasing power and people would feel richer. As a result, the poverty level decreased. Accordingly, people's purchasing power should be increased in real and nominal terms, if the government wanted to decrease poverty. In order to increase real income, the government should keep price stability to avoid price fluctuation that caused low purchasing power. If the government has capability, the government will increase their employees' salary and social assistance in terms of varieties and nominal by maintaining price stability so that the salary increases and social assistance influence positively.

Sanitation also influenced negatively towards average poverty in provinces of Indonesia [13]. The sanitation in this term means the percentage of households with access to proper and sustainable sanitation for $40 \%$ of lower classes. It means that the bigger the household with access to proper and sustainable sanitation, the bigger people's capability to maintain their health. A well-maintained health makes people have good ability to work and be capable to fulfill their basic needs and as a result, the poverty level decreases. Government should promote public sanitation building policies, especially in poor, remote, and isolated areas in order to give more access to sanitation service. On the other hand, the importance to maintain health by using proper and sustainable sanitation should also be promoted.
Educational level influences poverty decrease [14]. A research stated that Net Enrollment Rate of Senior High School (APMSMA) influenced negatively towards average poverty level in provinces of Indonesia. It means that the bigger the number of high school students compared to the number of the population in high school age, the lower the poverty level. It happens as the high school-graduated workforce is easier to find a job compared to the ones graduated below them. The fact also shows the average vocation requires someone who at least graduated from high school. It means, the more high school-graduated students, the bigger their chance to get the job compared with the ones that graduate below high school level. That's why the accomplishment of 12-year Compulsory Education should be promoted and even increased into 15-year Compulsory Education. It is expected that the average Indonesian people are high school-graduated, not elementary school-graduated like in this current situation. Currently, the average level of school-age in Indonesia is 8 years and it hasn't even graduated from junior high school.

Gini ratio influenced positively towards poverty in provinces of Indonesia [15]. The smaller Gini ratio, the lower income imbalance. The lower income imbalance, the lower social injustice, and thus, it creates the harmonious-maintained social life and peace and automatically the poverty level is decreasing. Accordingly, the government should be able to decrease income imbalance with their policies. If all people are fairly treated, the government's aim of creating justice and prosperity as stated in UUD 1945 is possibly achieved and not merely political jargon.

\section{CONCLUSION}

The research result shows that Gross Regional Domestic Bruto per capita, sanitation, and net enrollment rate of senior high school (APMSMA) have negative influence, while Gini Ratio has positive influence towards poverty in provinces of Indonesia. Besides, there are 14 provinces that have higher poverty percentage than the average province poverty in Indonesia.

\section{REFERENCES}

[1] M. P. Todaro and S. C. Smith, Economic Development $9^{\text {th }}$ Edition, Pearson, 2006.

[2] O. Galor,"Income Distribution and The Process of Development", European Economics Review, 44:706 - 712, 2000

[3] G. Kartasasmita, Pembangunan Untuk Rakyat, Memadukan Pertumbuhan dan Pemerataan, Jakarta: Cidessindo, 1996.

[4] World Bank, World Developing Report 2000/2001: Attacking Poverty, Oxford University Press, Inc., 2000

[5] A. Azra, Poverty and Inequality in Indonesia: Estimates, decomposition and key issues. Journal of the Asia Pacific Economy · February, 2000.

[6] Michael M.O. Seipel, Global Poverty: No Longer an Untouchable Problem. Internationla Social Work 46 (2): 191-207,2000.

[7] Ravallion M. Datt G, "How Important To India's Poverty is The Sectoral Compotition of Growth?" World Bank Economic, 10: 1-25, 1996.

[8] M. Mihai, E. Titan, and D. Manea. Education and Poverty. Procedia Economics and Finance 32 (2015): 855-860, 2015.

[9] H. Siregar and D. Wahyuniarti," Dampak Pertumbuhan Ekonomi Terhadap Penurunan Jumlah Penduduk Miskin", http://pse.litbang.deptan.go.id/ind/pdffiles/Pros, 2008. 
[10] H. Dagderiven, R. Van Der Hooeven and J. Weeks, "Redistribution Does Matter: Growth and Redistribution for Poverty Reduction" Discussion Paper. United Nation University/WIDER, 2002.

[11] D.N. Gujarati, Basic Econometrics, Fourth Edition, New York: McGraw-Hill, 2003.

[12] Badi H. Baltagi,Econometric Analysis of Panel Data, Second Edition, John Wiley \& Sons Inc., 2001.M. L.

[13] F.A. Abulude and S.D. Fagbayide, Water, Sanitation and Poverty in the Changing World: Case of Nigeria. (May 2018) www.researchgate.net/publication/325205967

[14] M. L. Jhingan, The Economics of Development and Planning, New Delhi: Vices Publishing House, Ltd, 1983.

[15] Frank A. Farris, The Gini Index and Measures of Inequality. The American Mathematical Monthly. December 2010 